\title{
17
}

\section{Building Positive Emotions and Playfulness}

\author{
Louise Tidmand
}

In most positive childhood memories, fun, playfulness, and positive emotions are present. When we think of such a memory, we might even able to relive and savour that moment repeatedly, thanks to our ability to collect somatic markers. Somatic markers refer to the juxtaposition of image, emotion, and bodily feelings that we generate during an experience (Damasio, Everitt, \& Bishop, 1996; Muñoz, 2017). Through emotions, according to Damasio et al. (1996), we build "innate and acquired knowledge concerning bioregulatory processes and body states and actions" (p. 1414). With reference to Aristotle in Rhetoric, emotions as somatic markers are psychophysical processes in which the rational component is influenced by the bodily component (Muñoz, 2017).

Often, we use the words emotions and feelings interchangeably, but they are different. Emotions are our response to a physiological condition, a reaction to stimulus, whereas feelings are our subjective experience and interpretation of stimuli response (Fredrickson, 2011; Holmgren, Ledertoug, Paarup, \& Tidmand, 2019). Our experiences with positive and negative emotions affect our feelings and thoughts, and they may release either a positive upwards spiral or a negative downwards spiral.

L. Tidmand $(\bowtie)$

Aarhus University, Aarhus, Denmark

e-mail: loti@edu.au.dk 


\section{Positive Emotions and Somatic Markers}

Building positive emotions and collecting positive somatic markers is like filling up your personal account of emotions (as if it were a bank account), aiming at having more positive emotions than negative emotions in that account, and in this way contributing to your own wellbeing. Positive emotions generate positive somatic markers, and our emotions influence our cognition (Kahneman, 2012); in other words, our body remembers the emotions connected to an experience and the emotions influence the way we think about that experience. We may recall the memory of that positive experience from recognizing a smell, a sound, a view, or anything that is part of that memory and we are more likely to repeat the action connected to the positive memory (Damasio, 2004). In education, we may build positive somatic markers through positive emotions and experiences that our students will integrate as part of their resources.

The influence of positive emotions on learning may be explained by the connection between positive emotions and divergent and creative thinking, as well as the connection between negative emotions and convergent thinking (Guilford, Merrifield, \& Cox, 1961) or by the Broaden and Build theory (Fredrickson, 2001). Positive emotions influence our mood and our ability to think creatively and generate variable possible solutions to a problem or a task. When experiencing positive emotions, we broaden our mind, we are able to think innovatively, to see things from diverse perspectives, and our thinking is flexible. When experiencing negative emotions, we tend to look for one correct solution only. The Broaden and Build theory argues that the range of our immediate thought and action repertoire-our cognition and our attention-expand when we experience positive emotions, and we generate change from our divergent thinking that builds our personal resources and releases an upwards spiral of positive emotions (Fredrickson, 2001; Fredrickson \& Branigan, 2005; Holmgren et al., 2019). There is a dialectic connection between positive emotions, good mood, and cognitive flexibility. So when developing coping and learning strategies, the coping flexibility denotes cognitive astuteness in formulating coping strategies to meet specific situational demands and the possession of meta-coping skills that foster the implementation of flexible coping strategies (Cheng, Lau, \& Chan, 2014).

In short, positive emotions have an invigorating and lasting effect on our personal resources. They facilitate further growth because they influence and change the way our brain works and allow us to develop our thought and action repertoire and expand our field of vision and attention. Research focuses on ten positive emotions: joy, interest, gratitude, hope, 
serenity, amusement, pride, awe, inspiration, and love. Fredrickson (2011) suggests that the latter may be seen as a superior emotion as it contains all the other nine emotions.

When building positive emotions and playfulness in positive education, the focus is relevant to every person who spends work hours at the educational institution, whether they are teachers, students, office staff, or administrators.

\section{Playfulness and Play}

There is a distinction between play and playfulness; play is a behaviour and playfulness a personality predisposition that allows the individual to transform a situation or environment to be more enjoyable or entertaining (Barnett, 1990, 2007; Glynn \& Webster, 1992; Schaefer, 1993; Trevlas, Grammatikopoulos, Tsigilis, \& Zachopoulou, 2003).

One definition of playfulness is: "in part, an openness to being a fool, which is a combination of not worrying about competence, not being selfimportant, not taking norms as sacred and finding ambiguity and double edges a source of wisdom and delight" (Lugones, 1987 p. 17). In the words of Barnett (2007), playfulness is defined as "the predisposition to frame (or reframe) a situation in such a way as to provide oneself (and possibly others) with amusement, humour, and/or entertainment" (p. 955). Research into the correlation between wellbeing and playfulness is only a century old. However, it has become apparent that playfulness is a potent and powerful instrument for wellbeing and even life expectancy (Gordon, 2014). Also, optimism and self-perception are affected positively with students when consciously working with experiencing positive emotions in school (Andersen \& Tidmand, 2014; Tidmand, 2018).

Play as behaviour may be the optimal frame for experiencing and being playful. The flow that occurs when we play, no matter what strength profile we otherwise possess, makes play an activity we just do because it is fun. Like other top strengths, it does not feel stressful, because we are not associating it with some future reward (Rana, 2018). Play is by nature autotelic and contains in itself the potential for flow (Csikszentmihalyi, 2014).

Play aims to either train us physically, socially, or cognitively. Playfulness can thus be the unencumbered state that allows you to explore your environment and understand the boundaries that can guide your future experiences. Rana (2018) argued that you spend the first part of your life exploring, seeing, and understanding, but once your curiosity about your 
surroundings has levelled to a satisfactory level, you start to exploit the knowledge you have gained.

Nevertheless, in the twenty-first century, our surroundings are rapidly changing. In the Volatile, Uncertain, Complex, and Ambiguous (VUCA) world, exploration and exploitation phases melt together and overlap, if you want to succeed. Not making room for play in the modern adult life is a strategic disadvantage-exploration and exploitation are no longer distinct, but continually co-evolving as the world unfolds around us (Rana, 2018), and playfulness is a necessary part of your adult life and your work experience.

However, humans are pruned to lose the playfulness associated with childhood. It is argued that humans are born with an animal nature and through upbringing, Bildung (education and formation), and primarily development of language, they acquire a mind, cognitive skills, reason, and a kind of second (human) nature that is often perceived as seriousness, which is understood as the opposite of playfulness (Bakhurst, 2011). Playfulness is thus unlearned through our culture, which explains why it is mostly associated with childhood.

With the rapidly changing surroundings and the fusion of the exploration and exploitation phase, playfulness and humour as a character trait may be construed as an advantage in education as well as in the workplace. Studies show that playfulness in adults correlates with intrinsic motivation (Amabile, Hill, Hennessey, \& Tighe, 1994), creativity and spontaneity (Barnett, 2007; Glynn \& Webster, 1992), positive attitudes towards the workplace or job satisfaction (Yu, Wu, Chen, \& Lin, 2007), and academic achievement (Proyer, 2012; Proyer \& Ruch, 2011), all highly desirable qualities in a workplace or in education.

Play can facilitate positive emotions and thus broaden the mindset (Fredrickson, 1998, 2001) encouraging novel, varied, and exploratory thoughts and actions, creating the urge to be creative when creativity is needed. So, play can consciously be used to broaden habitual modes of thinking and acting (Fredrickson, 1998, 2001). Playful people tend to perceive a lower level of stress (Magnuson $\&$ Barnett, 2013) and use adaptive coping strategies (Leung Chun Lok, 2014).

In positive psychology, the term playfulness is an important part of the Values in Action (VIA) strength of humour (Peterson \& Seligman, 2004). The VIA Institute on Character describes playfulness as the core of humour and playfulness as a generator for reinvigorating the strength humour, and describes six ways of expressing playfulness (http://viacharacter.org): 
- Spontaneous: Are you ever impulsive, adventurous, carefree, or freespirited?

- Expressive: Are you ever animated and emotional, bouncy and open, or feel as if you are manifesting joy?

- Creative: Are you ever actively imaginative and original?

- Fun: Are you ever excitable and playful (the opposite of dull)?

- Silly: Are you ever childlike and whimsical?

Peterson and Seligman (2004) noted that humour appears in many forms:

The domain of humour is vast and varied, and there exists a huge terminology for describing its types. Some forms are clearly mean (e.g., mockery, ridicule, sarcasm), and others on the border (e.g., parody, practical jokes). We exercise our prerogative by focusing on those forms of humour that serve some moral good - by making the human condition more bearable by drawing attention to its contradictions, by sustaining good cheer in the face of despair, by building social bonds, and by lubricating social interaction. (p. 530)

According to Gordon (2014), playfulness and engaging in play unfolds a number of adaptive and cognitive changes. Many researchers have pointed out aspects of these adaptive and cognitive changes. Table 17.1 identifies some of these.

One may argue that if playing is ignored or under-stimulated, it might have potentially negative biological consequences, much like if sleeping and dreaming is ignored and/or under-stimulated (Brown, 2008). But play also has a purpose; research has established that children engage in make-believe play, where they mimic adults as a tutorial for coping with real-life challenges (Lancy, 2014). Such imitation is emphasized by both Vygotsky and Elkonin (1978), who highlighted that make-believe play develops self-regulation; in agreeing on the details of the play (e.g., casting roles and agreeing on the use of props), some planning is needed (Ëlkonin, 1978). That planning and learning to adjust actions to the norms associated with the character's behaviour and abstaining from actions that are not consistent with the character's role are steps to self-regulation, self-monitoring, and intentional behaviour (Bodrova, Germeroth, \& Leong, 2013).

\section{Vygotsky's View on Play and Playfulness}

In Play and Its Role in the Mental Development of the Child, Russian psychiatrist Lev S. Vygotsky (1967) stated: 
Table 17.1 Adaptive and cognitive changes impacted by playfulness

\begin{tabular}{|c|c|}
\hline Adaptive/cognitive change & Source \\
\hline Training for the unexpected & Spinka, Newberry, and Bekoff (2001) \\
\hline Problem-solving, divergent thinking & $\begin{array}{l}\text { Baer (1993, 2014), Barnett (1985), } \\
\text { Barnett and Kleiber (1982), } \\
\text { Lieberman (1965), and Vandenberg } \\
(1980)\end{array}$ \\
\hline Skills for cooperation & Spinka et al. (2001) \\
\hline $\begin{array}{l}\text { The ability to interpret ambiguous social } \\
\text { cues }\end{array}$ & Pellis (2010) and Spinka et al. (2001) \\
\hline Positive affect & $\begin{array}{l}\text { Barnett (1991) and Jenvey and Jenvey } \\
\text { (2002) }\end{array}$ \\
\hline $\begin{array}{l}\text { The ability to find meaning in } \\
\text { experiences, or meaning-making }\end{array}$ & Bruner (1990) \\
\hline $\begin{array}{l}\text { Imagination, creativity, teamwork, and } \\
\text { even perceived stress and styles of } \\
\text { coping }\end{array}$ & $\begin{array}{l}\text { Barnett (1991), Lieberman (2014), } \\
\text { Lurie and Monahan (2015), } \\
\text { Magnuson (2011), and Singer, Singer, } \\
\text { and Sherrod (1980) }\end{array}$ \\
\hline Emotional and self-regulation & $\begin{array}{l}\text { Christiano and Russ (1996) and Elias } \\
\text { and Berk (2002) }\end{array}$ \\
\hline $\begin{array}{l}\text { Metacommunication, or communication } \\
\text { about communication }\end{array}$ & Bateson (2006) \\
\hline Affect-regulation, or emotional stability & Berk, Mann, and Ogan (2006) \\
\hline $\begin{array}{l}\text { Self-transformation, or flexible identity } \\
\text { and the ability to pretend }\end{array}$ & $\begin{array}{l}\text { Garvey (1990) and Schwartzman } \\
(2012)\end{array}$ \\
\hline Symbolic representation & Piaget (2013) \\
\hline $\begin{array}{l}\text { The ability to communicate coherent } \\
\text { narratives }\end{array}$ & Nicolopoulou (2005) \\
\hline $\begin{array}{l}\text { The ability to be a peaceful, productive } \\
\text { member of community }\end{array}$ & Sutton-Smith (2009) \\
\hline $\begin{array}{l}\text { The social competence it takes to } \\
\text { get along with others }\end{array}$ & Connolly and Doyle (1984) \\
\hline The ability to express oneself creatively & Singer and Singer (1998) \\
\hline
\end{tabular}

In play a child is always above his average age, above his daily behaviour; in play it is as though he were a head taller than himself. As in the focus of a magnifying glass, play contains all developmental tendencies in a condensed form; in play it is as though the child were trying to jump above the level of his normal behaviour. (p. 16)

Vygotsky believed that human development was a dialectic play between the processes of natural, biologically determined development, and cultural development created by interactions with other people. The lower (biologically determined) mental functions (e.g., involuntary attention, sensorymotor thought) are restructured to higher mental functions (Bodrova \& Leong, 2015). Vygotsky (1997) stated that "when the child enters into 
culture, he not only takes something from culture ... but culture itself profoundly refines the natural state of behaviour of the child and alters completely anew the whole course of his development" (p. 223).

Vygotsky defined higher mental functions as behaviour that is signmediated, intentional, and internalized. The development of higher mental functions is a gradual process from interindividual, or shared, to individual. Therefore, Vygotsky viewed early childhood to be the stage allowing children to make a transition from slaves of the environment to becoming masters of their own behaviour. Put in other words, education in preschool years should take aim at overcoming the child's impulsive, reactive behaviour and supporting children to become capable of intentional behaviour (Bodrova $\&$ Leong, 2015). This context is important to understand Vygotsky's view on play.

Vygotsky focused on sociodramatic play or make-believe play typical for pre-schoolers and children of primary school age. Vygotsky believed the sociodramatic play had three features - an imaginary situation, roles, and rules-that served to develop higher mental functions. He identified the creation of an imaginary situation and the casting of roles as the child's emerging ability to perform external and internal actions. In play, identifying internal actions is the equivalent of understanding dependence on external factors and their influence on their character/role and the situation, and that, to Vygotsky, was evidence of the emergence of more advanced symbolic thought and higher mental functions (Bodrova \& Leong, 2015).

Play promotes intentional behaviour because it requires children to understand the mutual relationships between the roles they play and the rules they need to follow when playing these roles. Vygotsky (1967) noted:

At that critical moment when a stick becomes a pivot for severing the meaning of a horse from a real horse, one of the basic psychological structures determining the child's relationship to reality is radically altered. (p. 12)

At this stage, the child understands that a prop does not have to look like the object it symbolizes in the game but has to have similar properties to the real object; for example, a bucket can be a ship because it can float. The symbolic train of thought unconstrained by reality and the child's ability to assign new meaning to objects is a transitional stage for achieving mastery of the object and furthering symbolic ability (Bodrova \& Leong, 2015).

Vygotsky (1967) similarly regards play as a transitional stage in developing imagination, thus opposing the common understanding that imagination is a prerequisite for play. Imagination is not a formation in the consciousness of 
a young child, totally absent in animals and is thus a formation closely linked to consciousness and higher mental function:

Play continually creates demands on the child to act against immediate impulse ... Why does the child not do what he wants, spontaneously and at once? Because the play promises much greater pleasure than the gratification of an immediate impulse. (p. 14)

Play is autotelic; it is engaged in for its own sake, with the reward intrinsic to the activity itself. Although the activity is not essential for survival or profit, play commands a person's entire attention.

Vygotsky (1967) further explained that:

play is the source of development and creates the zone of proximal development. Action in the imaginative sphere, in an imaginary situation, the creation of voluntary intentions, and the formation of real-life plans and volitional motives-all appear in play and make it the highest level of preschool development. (p. 16)

Vygotsky's learning precedes development. He argued that our present state of development is enhanced when presented with tasks just out of reach of our present abilities. The gap between our pre-existing development and what we can accomplish with the help of others is called the Zone of Proximal Development. He does not limit this to one-on-one situations of teaching or tutoring, but sees play as a means of assistance provided by a group of peers. This group appears collectively as a more knowledgeable other, although none of the group members are more knowledgeable than other children in the group (Bodrova \& Leong, 2015).

So, in Vygotsky's understanding of play, playfulness, or the strength humour is a resource in a learning environment and a lever for learning or academic performance, thus opposing the common understanding that some strengths are less suitable for learning environments like schools (e.g., the VIA virtue category of Transcendence) and reinforcing that idea that all strengths are equal.

\section{What Happens in the Brain During Play}

To understand how playfulness, positive emotions, and humour affect our performance, it is important to understand how the brain is affected by these experiences. According to Willis (2016), laughter and smiles trigger a network 
of subcortical structures, including the ventral tegmental area, hypothalamus, nucleus accumbens (NAcc), and amygdala-key components of the mesolimbic dopaminergic reward system. Therefore, the chemical reward system and the positive emotions trigger the Broaden and Build process that enables us to broaden our mindset, think more creatively, and be innovative in solving our assignments. To best process information and learn, there is heavy traffic from sensory receptors (visual, auditory, touch) to memory storage regions of the brain. These bits of data are carried from one nerve cell to another by neurotransmitter. But neurotransmitters are in limited supply at each gap between the nerve cells and deplete in as little as ten minutes when you stress that particular neural network (i.e., continue) the same type of learning activity (e.g., attentive listening, taking notes, etc.). Thus, using Brain Breaks ${ }^{1}$ to shift the type of mental activity, shifts brain communication to networks with fresh supplies of neurotransmitters. This intermission allows the brain's chemicals to replenish within the resting network.

Similarly, the laughter generated from a prank or joke activates a different network than listening to a conversation, a lecture, solving a problem, or writing a report, and forces you to focus on positive emotions, thus shifting the neural network. The laughter is involuntary and cannot be dismissed, and can serve to interrupt your routines, and improve your emotions during the workday. Diamond, Krech, and Rosenzweig (1964) tied play to increases in certain neural functions. Diamond was inspired by research in 1960 that contested that the brain is immutable, subject only to genetic control. This led her to perform an experiment with rats, one group in boring, solitary confinement and another group in exciting toy-filled colonies.

Diamond found that rats raised in stimulating environments developed bigger brains and were able to find their way through mazes more quickly. Furthermore, she found that stimulated rats showed increased levels of brainderived neurothropic factor (BDNF) in their brains. BDNF is a protein that protects existing brain cells and stimulate growth of new brain cells and their mutual connections. In a later experiment, she expanded the experiment to include older rats with the same result (Diamond, 2001).

Sylva, Bruner, and Genova (1976) documented a positive relationship between a play versus training experience and divergent problem-solving abilities, thus indicating that play experiences are beneficial for a task that requires innovative transfer (Smith \& Dutton, 1979).

\footnotetext{
${ }^{1}$ Brain breaks are mental breaks designed to help students stay focused and attentive. Brain breaks are often hand-eye coordination exercises. The brain breaks get students moving to carry blood and oxygen to the brain. The breaks energize or relax (The Watson Institute).
} 
Individuals with humour as their top strength often earn a reputation for that characteristic in social networks or organizations where they use the role as the class (or organizational) clown to emphasize signs of hybris in leaders, address taboo topics, and help calm strained situations. The class clown can thus satirize leaders, followers, and venture into otherwise forbidden territories. The person can work as a corrective force against the leadership in organizations or as a mediator between leaders and followers (Wagner, 2019).

Neoteny is the retention of immature qualities into adulthood (Brown, 2008) and that retention unlocks the above potentials in adulthood. Playfulness increases positive emotions and decreases negative emotions (Chang, Qian, \& Yarnal, 2013) and university students characterized as more playful were more reluctant to seek companionship (Qian \& Yarnal, 2011) thus implying that playful people have more positive relationships. Positive relationships contribute to flourishing (Seligman, 2011). The autotelic actions, like playful activities, make flow experiences more likely (Csikszentmihalyi, 2014), inducing long-lasting happiness (Lyubomirsky, 2008).

Pepler and Ross (1981) described how children who played with convergent materials prior to the problem-solving task performed better on convergent problems, whereas play experience with divergent materials appeared to transfer both to divergent and convergent problems, and the divergent playgroup appeared more flexible in abandoning ineffective strategies in seeking solutions (Pepler \& Ross, 1981). Convergent problems are problems with one and only one solution (e.g., puzzle pieces). Divergent problems have no single correct solution, but a variety of possible solutions (e.g., building blocks). Smith and Dutton (1979) repeated the experiment but extended the play versus training paradigm to direct and innovative problem-solving. Given a more complex assignment, not directly trained with the training group, the playgroup outperformed the training and control groups, thus indicating that play experiences improved the ability to solve tasks that required innovative transfer. Subsequent studies indicated a causal and reciprocal connection between pretend play and divergent problem-solving skills (Wyver \& Spence, 1999); children given training in pretend play showed increased ability to solve divergent problems and children trained in solving divergent problems displayed increased rates of pretend play. 


\section{Positive Emotions and Playfulness as Part of the Educational and Work Culture}

An educational institution is a workplace for both staff and students. Implementing positive education helps create a school culture and environment conducive to positive emotions for both staff and students. Often, when we as educators implement a pedagogical and/or didactical framework into our practice, the focus is on applying an approach to the students. Positive education is a broader approach, addressing everyone associated with the educational enterprise, from students to teachers to staff. Building the positive emotions and playfulness of staff will not only improve their wellbeing and job satisfaction, but it will also multiply so that educators will build positive emotions and playfulness of students and in classrooms. Other types of organizations may provide examples of how a more playful working environment may be established.

Companies that promote positive emotions allow their employees to express themselves as individuals, talking with their customers/students in informal ways rather than reading from a script. Apart from the positive impact on innovation and productivity (Pentland, 2012), such environments also have been linked to enhanced job satisfaction (Karl \& Peluchette, 2006) and decreased absenteeism (Meyer, 1999). Within this context, the personality of each employee surfaces, and thus playfulness empowers the employee to exercise autonomy and, with colleagues' and students'/customers' immediate responses (e.g., laughter), promotes a sense of competence and relatedness, thus addressing the basic psychological needs described by SelfDetermination Theory (Deci \& Ryan, 2000). As such, workplace playfulness can be helpful in generating wellbeing and job satisfaction.

Some companies and philosophies in practice that may inform educational institutions on how to build positive emotions and playfulness at the workplace include:

- Fish! Philosophy. The Fish! Philosophy was created in 1997 by John Christensen (https://www.fishphilosophy.com/fish-philosophy-story/). He visited the Pike Place Fish Market in Seattle, Washington, and noticed employees at one particular fish stall who- to his surprise-were laughing, shouting, and tossing trout and salmon through the air, while joking with the customers as if they were old friends. He later learned that the fish sellers' job was exhausting and repetitive, and that these employees in this particular stall had chosen a playful attitude when coming to work that made the job more enjoyable not only to themselves, but also to customers. 
Fish! Philosophy later became an entire management theory in the corporate world and has revolutionized the rigid attitude to customer service. The Fish! Philosophy theory taps into the benefits of playfulness in the employees, invigorates the workplace, helps position the corporation, and generates customer satisfaction and retention.

- The rapping flight attendant. David Holmes worked as a flight attendant with Southwest Airlines. One of his jobs was to make the tedious security announcement before take-off. David began rapping this security announcement when he was in a good mood and wanted to inject some fun into work, and especially when flying back to his hometown, Las Vegas, Nevada (https://youtu.be/68pSH1sWzOU). In some companies, that kind of behaviour would have resulted in termination on the spot, but David worked at Southwest Airlines, which encourages playfulness in the workplace as a strategy to stand out from other airlines. Customers enjoyed it and colleagues found it fun and entertaining. David is now only one of many mostly Southwestern flight attendants that joke around and make humorous announcements.

- Google. Google prides itself as being on top of Fortune's list of "Best Companies to Work For" for six consecutive years and has regularly been on Glassdoor's annual "Best Places to Work" list. One of a number of philosophies that Google has implemented in the workplace is "Despite rigorous tasks, Google keeps things fun”. Google's former HR-boss, Laszlo Bock, stated that "keeping things fun in a hive of activity, constant innovation, and experiment discharges employees' creativity juice. What's beautiful about this approach is that a great environment is a self-reinforcing one: All of these efforts support one another, and together create an organization that is creative, fun, hardworking, and highly productive".

- Teacher morning handshake. At Wichita Public Schools' Mueller Elementary in Kansas, one teacher starts every morning by giving playful and individually designed handshakes to her students (https://www.you tube.com/watch?v=3VzOmZ4bdTw). This way she connects with every student and starts both her and their day building positive emotions in a playful way.

\section{Building Positive Emotions and Playfulness in Pedagogical Practice}

Having looked at what positive emotions, play, and playfulness are and why positive emotions and playfulness are fundamental to positive education, it is now time to look at the how of building positive emotions and playfulness. 
The following examples and suggestions demonstrate how positive emotions and playfulness may be built explicitly and implicitly in teaching, including in preparation and lesson planning, pedagogical practices in the classroom, and evaluation of the lesson.

When preparing a lesson plan, the first thing to do should be to think of the group of students. How well do you know them and what may create a positive and safe learning environment? What has gone well in your previous lessons or lectures? You might want to introduce and make use of Brain Breaks, handshakes, music, or YouTube clips that will engage the students to laugh and create a positive environment. You may also explore your own approach to being playful. When and where are you playful? And what would happen, if you were more playful and used humour when teaching? The idea is not that educators need to become stand-up comedians, but that taking small actions to demonstrate our own playfulness will have positive benefits for students, even when we are introducing academic subjects or lesson content or in activities connected to a learning task.

When planning and teaching, we may be aware of how we can involve and engage students, and build positive emotions and playfulness using the model in Table 17.2. The model illustrates how we are able to adjust our teaching so as to focus on enabling students to experience not only playfulness and positive emotions, but also autonomy, competence, and relatedness in connection to lesson content and/or lesson activities. We may choose to have fixed content, but choose to have an open activity where students themselves give input as to how they will learn the content/solve a problem/work with the material. We might have a fixed idea about the structure of activity and at the same time be open as to what content this activity structure has to be applied. We might have an open activity structure and an openness to the content to which the activity is connected. Finally, we might have a fixed content and a fixed activity connected to the content. The latter scenario may leave less room for experiencing autonomy, competence, and relatedness as well as playfulness.

The model depicted in Table 17.2 is inspired by a Danish project from 1986 working with student involvement in physical education (Fibæk Lauersen, 1994; Rønholt \& Peitersen, 2008). An example may be around a

Table 17.2 Model for planning for student positive emotions and playfulness in teaching

\begin{tabular}{ll}
\hline Fixed content/Open activity & Open content/Fixed activity \\
Fixed content/Fixed activity & Open content/Open activity \\
\hline
\end{tabular}

Source adapted from Fibæk Lauersen (1994) and Rønholt and Peitersen (2008) 
language subject, where the subject curriculum requires that students read a fiction novel and work with describing characters in the novel, as depicted in Table 17.3. The model may also be used to differentiate content and activity in the class, and to adjust the didactic choices when planning.

During teaching, awareness about how the brain works can inspire us to change activities and/or content during a lesson. As mentioned before, Brain Breaks offer a means to incorporate variety in activities, but other types of breaks may serve the purpose of building positive emotions as well as refreshing the brain. Other types of breaks may focus on lowering the energy level in the classroom, and the break could be a short mindfulness exercise or a short meditation or listening to a calm piece of music while focusing on the breath. Another type of break could be savouring a somatic marker by taking a moment to go down memory lane and revisit positive experiences. Such a trip down memory lane may be a guided one, where the teacher guides the students to revisit for instance their best memory from a day at the beach, a day in the forest, a play experience, a favourite moment with the family or with a friend, a favourite school day, or other contexts that the teacher might find suitable for the specific group of students.

Playfulness and play during teaching curriculum of any subject may be implemented by using different kinds of building materials such as LEGO, play dough, blocks, paper, cans, centicubes, etc., where students of any age individually or in groups either build a dilemma/situation/task that needs solving and solve it by making changes in their building, or simply use the building aspect as a way to communicate and illustrate divergent thinking. When using divergent building materials, the students experience working with representations by choosing props to look like or symbolize a specific object. Many academic problems, challenges, and tasks that we normally

Table 17.3 Example of the model's application in language arts class

\begin{tabular}{|c|c|}
\hline $\begin{array}{l}\text { Fixed content/Open activity: All read the } \\
\text { same novel/Each student chooses two } \\
\text { characters that they will describe and how } \\
\text { they will do this (in writing, role-playing, } \\
\text { painting, riming, singing, etc.) }\end{array}$ & $\begin{array}{l}\text { Open content/Fixed activity: Each } \\
\text { student freely choose a fiction } \\
\text { novel/All describe the two main } \\
\text { characters of the novel in a } 250 \\
\text { word written assignment }\end{array}$ \\
\hline $\begin{array}{l}\text { Fixed content/Fixed activity: All read the } \\
\text { same novel/All describe the two main } \\
\text { characters in a } 250 \text { word written } \\
\text { assignment }\end{array}$ & $\begin{array}{l}\text { Open content/Open activity: Each } \\
\text { student freely chooses a fiction } \\
\text { novel/Each student chooses two } \\
\text { characters that they will describe } \\
\text { and how they will do this (in } \\
\text { writing, role-playing, making a } \\
\text { short movie, painting, riming, } \\
\text { singing, etc.) }\end{array}$ \\
\hline
\end{tabular}


teach through dialogue or in writing, might just as well be scrutinized using divergent (building) materials.

Encourage the students to take pictures of their building process and final construction. This is a way to celebrate good work and the pictures may become a representation of an important somatic marker for the student as well as contribute to the student developing self-efficacy.

When evaluating teaching, educators should focus on what went well and on evaluating progress on goals that were set before the teaching session. Before actually teaching a lesson, educators should ask: What do I plan for? What do I hope will happen? What criteria do I set for my self-evaluation? When, during your teaching, did you feel positive emotions or playfulness? How might this motivate you when planning your next teaching lesson? When evaluating students, ask them the same questions: When during your learning process do you feel the most positive emotions, the most playful, or the most motivated? How may this inspire your learning in the future?

\section{Conclusion}

The positive emotion and playfulness experiences that we experience during our time in education have the potential to create important positive somatic markers that become a lifelong resource for the individual person and for the educational institution.

\section{References}

Amabile, T. M., Hill, K. G., Hennessey, B. A., \& Tighe, E. M. (1994). The work preference inventory: Assessing intrinsic and extrinsic motivational orientations. Journal of Personality and Social Psychology, 6, 950-967.

Andersen, F. Ø., \& Tidmand, L. (2014). Hvordan børn lærer sig nye handlemuligheder og kompetencer - en undersøgelse af indsatser i folkeskolen baseret på positiv psykologi. Padagogisk Psykologisk Tidsskrift, 51. argang (2).

Baer, J. (1993, 2014). Creativity and divergent thinking: A task-specific approach. https://doi.org/10.4324/9781315806785.

Bakhurst, D. (2011). Formation of reason. Hoboken, NJ: Wiley-Blackwell.

Barnett, L. A. (1985). Young children's free play and problem-solving ability. Leisure Sciences, 7(1), 25-46. https://doi.org/10.1080/01490408509512106.

Barnett, L. A. (1990). Playfulness: Definition, design, and measurement. Play and Culture, 3(4), 3. 
Barnett, L. A. (1991). Characterizing playfulness: Correlates with individual attributes and personality traits. Play and Culture, 4(4), 371-393.

Barnett, L. A. (2007). The nature of playfulness in young adults. Personality and Individual Differences, 43(4), 949-958. https://doi.org/10.1016/j.paid.2007. 02.018 .

Barnett, L. A., \& Kleiber, D. A. (1982). Concomitants of playfulness in early childhood: Cognitive abilities and gender. The Journal of Genetic Psychology, 141(1), $115-127$.

Bateson, G. (2006). A theory of play and fantasy. In K. Salen \& E. Zimmerman (Eds.), The game design reader: A rules of play anthology (pp. 314-328). Cambridge and London: The MIT Press.

Berk, L. E., Mann, T. D., \& Ogan, A. T. (2006). Make-believe play: Wellspring for development of self-regulation. Play = learning: How play motivates and enhances children's cognitive and social-emotional growth (pp. 74-100). New York: Oxford University Press.

Bodrova, E., Germeroth, C., \& Leong, D. (2013). Play and self-regulation: Lessons from Vygotsky. American Journal of Play, 6, 111-123.

Bodrova, E., \& Leong, D. J. (2015). Vygotskian and post-Vygotskian views on children's play. American Journal of Play, 7(3), 371-388.

Brown, S. (2008). Play is more than just fun: TED Ideas worth spreading. https:// www.ted.com/talks/stuart_brown_says_play_is_more_than_fun_it_s_vital\#t18449.

Bruner, J. S. (1990). Acts of meaning (Vol. 3). Cambridge: Harvard University Press. Chang, P.-J., Qian, X., \& Yarnal, C. (2013). Using playfulness to cope with psychological stress: Taking into account both positive and negative emotions. International Journal of Play, 2(3), 273-296.

Cheng, C., Lau, H.-P. B., \& Chan, M.-P. S. (2014). Coping flexibility and psychological adjustment to stressful life changes: A meta-analytic review. Psychological Bulletin, 140(6), 1582-1607. https://doi.org/10.1037/a0037913.

Christiano, B. A., \& Russ, S. W. (1996). Play as a predictor of coping and distress in children during invasive dental procedure. Journal of Clinical Child Psychology, 25(2), 130-138.

Connolly, J. A., \& Doyle, A.-B. (1984). Relation of social fantasy play to social competence in preschoolers. Developmental Psychology, 20(5), 797.

Csikszentmihalyi, M. (2014). Play and intrinsic rewards. In Flow and the foundations of positive psychology (pp. 135-153). Springer.

Damasio, A. R. (2004). Emotions and feelings - A neurobiological perspective. In A. S. R. Manstead, N. Frijda, \& A. Fischer (Eds.), Feelings and emotions - The Amsterdam symposium (pp. 49-58). UK: The Press Syndicate of The University of Cambridge.

Damasio, A. R., Everitt, B. J., \& Bishop, D. (1996). The somatic marker hypothesis and the possible functions of the prefrontal cortex [and discussion]. Philosophical Transactions: Biological Sciences, 351(1346), 1413-1420. Retrieved from http:// www.jstor.org/stable/3069187. 
Deci, E. L., \& Ryan, R. M. (2000). The "what" and "why" of goal pursuits: Human needs and the self-determination of behavior. Psychological Inquiry, 11(4), 227268. https://doi.org/10.1207/S15327965PLI1104_01.

Diamond, M. C. (2001). Response of the brain to enrichment. Anais da Academia Brasileira de Ciências, 73, 211-220. Retrieved from http://www.scielo.br/scielo. php?script=sci_arttext\&pid=S0001-37652001000200006\&nrm=iso.

Diamond, M. C., Krech, D., \& Rosenzweig, M. R. (1964). The effects of an enriched environment on the histology of the rat cerebral cortex. Journal of Comparative Neurology, 123(1), 111-119.

Elias, C. L., \& Berk, L. E. (2002). Self-regulation in young children: Is there a role for sociodramatic play? Early Childhood Research Quarterly, 17(2), 216-238.

Ėlkonin, D. B. (1978). Psichologija igry. Pedagogika.

Fibæk Lauersen, P. (1994). Idratsdidaktikkens modernisering. Copenhagen: University of Copenhagen.

Fredrickson, B. L. (1998). What good are positive emotions? Review of General Psychiatry, 2(3), 300-319.

Fredrickson, B. L. (2001). The role of positive emotions in positive psychology: The broaden-and-build theory of positive emotions. Fra American Psychologist, 56, 218-226.

Fredrickson, B. L. (2011). Positivity: Groundbreaking research to release your inner optimist and thrive (New ed.). Oxford: Oneworld.

Fredrickson, B. L., \& Branigan, C. (2005). Positive emotions broaden the scope of attention and thought-action repertoires. Cognition and Emotion, 19(3), 313332.

Garvey, C. (1990). Play (Vol. 27). Cambridge: Harvard University Press.

Glynn, M. A., \& Webster, J. (1992). The adult playfulness scale: An initial assessment. Psychological Reports, 71(1), 83-103.

Gordon, G. (2014). Well played: The origins and future of playfulness. American Journal of Play, 6(2), 234-266.

Guilford, J. P., Merrifield, P. R., \& Cox, A. B. (1961). Creative thinking in children at the junior high school levels. Los Angeles: The Psychological Laboratory, The University of Southern California.

Holmgren, N., Ledertoug, M. M., Paarup, N., \& Tidmand, L. (2019). The battle against boredom In Schools. Copenhagen: The Strength Academy.

Jenvey, V. B., \& Jenvey, H. L. (2002). Criteria used to categorize children's play: Preliminary findings. Social Behavior and Personality: an International Journal, 30(8), 733-740.

Kahneman, D. (2012). Thinking, fast and slow. London: Penguin Books Ltd.

Karl, K., \& Peluchette, J. (2006). How does workplace fun impact employee perceptions of customer service quality? Journal of Leadership \& Organizational Studies, 13(2), 2-13.

Lancy, D. F. (2014). The anthropology of childhood: Cherubs, chattel, changelings (2nd ed.). London, UK: Cambridge University Press. 
Leung Chun Lok, R. (2014). Adult playfulness and its relationship to humour, subjective happiness and depression: A comparative study of Hong Kong and Mainland China. 3, 105-141. Retrieved from ssweb.cityu.edu.hk/download/RS/ E-Journal/Vol3/journal4.pdf.

Lieberman, J. N. (1965). Playfulness and divergent thinking: An investigation of their relationship at the kindergarten level. The Journal of Genetic Psychology, 107(2), 219-224.

Lieberman, J. N. (2014). Playfulness: Its relationship to imagination and creativity. New York: Academic Press.

Lugones, M. (1987). Playfulness, "world”-travelling, and loving perception. Hypatia, 2(2), 3-19.

Lurie, A., \& Monahan, K. (2015). Humor, aging, and life review: Survival through the use of humor. Social Work in Mental Health, 13(1), 82-91.

Lyubomirsky, S. (2008). The how of happiness: A scientific approach to getting the life you want. London: Penguin.

Magnuson, C. D. (2011). The playful advantage: How playfulness enhances coping with stress (Master Monograph). University of Illinois, USA.

Magnuson, C. D., \& Barnett, L. (2013). The playful advantage: How playfulness enhances coping with stress. Leisure Sciences, 35, 129-144. https://doi.org/10. 1080/01490400.2013.761905.

Meyer, H. (1999). Fun for everyone. Journal of Business Strategy, 20(2), 13-17.

Muñoz, J. M. (2017). Somatic markers, rhetoric, and post-truth. Frontiers in Psychology, 8(1273). https://doi.org/10.3389/fpsyg.2017.01273.

Nicolopoulou, A. (2005). Play and narrative in the process of development: Commonalities, differences, and interrelations. Cognitive Development, 20, 495-502.

Pellis, S. M. (2010). Conservative motor systems, behavioral modulation and neural plasticity. Behavioural Brain Research, 214(1), 25-29.

Pentland, A. S. (2012). The new science of building great teams. Harvard Business Review, 90(4), 60-69.

Pepler, D. J., \& Ross, H. S. (1981). The effects of play on convergent and divergent problem solving. Child Development, 52(4), 1202-1210. Retrieved from https:// www.jstor.org/stable/pdf/1129507.pdf.

Peterson, C., \& Seligman, M. E. P. (2004). Character strengths and virtues - A handbook an classification. New York, NY, USA: Oxford University Press.

Piaget, J. (2013). Play, dreams and imitation in childhood: London: Routledge.

Proyer, R. T. (2012). Examining playfulness in adults: Testing its correlates eith personality, positive psychological functioning, goal aspirations, and multimethodically assessed ingenuity. Psychological Test and Assessment Modeling, 54(2), $103-127$.

Proyer, R. T., \& Ruch, W. (2011). The virtuousness of adult playfulness: the relation of playfulness with strengths of character. Psychology of Well-Being: Theory, Research and Practice, 1(1), 4. https://doi.org/10.1186/2211-1522-1-4. 
Qian, X., \& Yarnal, C. (2011). The role of playfulness in the leisure stress-coping process among emerging adults: An SEM analysis. Leisure/Loisir, 35, 191-209. https://doi.org/10.1080/14927713.2011.578398.

Rana, Z. (2018, November 28). Why playfulness is the key to success in the 21st century. Personal Growth. Retrieved from https://medium.com/personal-growth/ why-playfulness-is-the-key-to-success-in-the-21st-century-201a626fe18.

Rønholt, H., \& Peitersen, B. (2008). Idratsundervisning - en grundbog $i$ idratsdidaktik. Copenhagen: Institut for Idræt, Museum Tusculanums Forlag, University of Copehagen.

Schaefer, C. E. (1993). The therapeutic powers of play. Lanham: J. Aronson.

Schwartzman, H. (2012). Transformations: The anthropology of children's play. New York: Springer Science \& Business Media.

Seligman, M. E. P. (2011). Flourish: A new understanding of happiness and well-being -and how to achieve them. London: Nicholas Brealey Pub.

Singer, J. L., \& Singer, D. G. (1998). Barney \& Friends as entertainment and education: Evaluating the quality and effectiveness of a television series for preschool children.

Singer, J. L., Singer, D. G., \& Sherrod, L. R. (1980). A factory analytic study of preschoolers' play behavior. Academic Psychology Bulletin.

Smith, P. K., \& Dutton, S. (1979). Play and training in direct and innovative problem solving. Child Development, 830-836.

Spinka, M., Newberry, R. C., \& Bekoff, M. (2001). Mammalian play: Training for the unexpected. The Quarterly Review of Biology, 76 (2), 141-168.

Sutton-Smith, B. (2009). The ambiguity of play. Cambridge: Harvard University Press.

Sylva, K., Bruner, J. S., \& Genova, P. (1976). The role of play in the problem-solving of children 3-5 years old. Play: Its role in development and evolution, 244-257.

Tidmand, L. (2018). My happy book in school. Denmark: The Strength Academy.

Trevlas, E., Grammatikopoulos, V., Tsigilis, N., \& Zachopoulou, E. (2003). Evaluating playfulness: Construct validity of the children's playfulness scale. Early Childhood Education Journal, 31(1), 33-39.

Vandenberg, B. (1980). Play, problem-solving, and creativity. New Directions for Child and Adolescent Development, 1980(9), 49-68.

Vygotsky, L. S. (1967). Play and its role in the mental development of the child. Soviet Psychology, 5(3), 6-18.

Vygotsky, L. S. (1997). The historical meaning of the crisis in psycholoogy: A methodological investigation. In R. W. Rieber (Ed.), Problems of the theory and history of psychology, the collected works of L. S. Vygotsky (Vol. 3, pp. 233-242).

Wagner, L. (2019). The social life of class clowns: Class clown behavior is associated with more friends, but also more aggressive behavior in the classroom. Frontiers in Psychology, 10(604). https://doi.org/10.3389/fpsyg.2019.00604.

Willis, J. (2016). Using brain breaks to restore students' focus. 
Wyver, S., \& Spence, S. (1999). Play and Divergent Problem Solving: Evidence Supporting a Reciprocal Relationship. Early Education \& Development, 10. https://doi.org/10.1207/s15566935eed1004_1.

Yu, P., Wu, J.-J., Chen, I.-H., \& Lin, Y.-T. (2007). Is playfulness a benefit to work? Empirical evidence of professionals in Taiwan. International Journal of Technology Management, 39(3-4), 412-429.

Open Access This chapter is licensed under the terms of the Creative Commons Attribution 4.0 International License (http://creativecommons.org/licenses/by/4.0/), which permits use, sharing, adaptation, distribution and reproduction in any medium or format, as long as you give appropriate credit to the original author(s) and the source, provide a link to the Creative Commons license and indicate if changes were made.

The images or other third party material in this chapter are included in the chapter's Creative Commons license, unless indicated otherwise in a credit line to the material. If material is not included in the chapter's Creative Commons license and your intended use is not permitted by statutory regulation or exceeds the permitted use, you will need to obtain permission directly from the copyright holder. 